\title{
Pismo „Głos SKOS-ów” jako źródło do analizy działalności opozycyjnej młodzieży poznańskiej w latach 80. XX w.
}

Poznań na początku lat 80. XX w. stał się ważnym ośrodkiem działań niepodległościowych młodzieży szkół średnich, głównie ogólnokształcących, ale też techników, w zakresie walki z ówczesnym systemem politycznym. Walkę tę prowadziły głównie niezależne organizacje młodzieżowe, zakładane przez młodych poznaniaków. Na terenie szkół średnich w Poznaniu działało kilka takich organizacji, funkcjonując z różnym nasileniem. Spośród nich najbardziej aktywne były: Konfederacja Młodej Polski - Rokosz, Szkolne Koła Oporu Społecznego, Wolny Licealista i Pokolenie Walczące - Warta. Wszystkie one znalazły się w okresie swej działalności w zasięgu obserwacji Służb Bezpieczeństwa, prowadzących wobec nich dość intensywne działania operacyjne ${ }^{1}$.

Jedną z największych spośród wymienionych była organizacja działająca pod nazwą Szkolne Koła Oporu Społecznego (SKOS). Organizacja ta powstała w marcu 1982 r. i funkcjonowała do września 1989 r. Czasowo działała jako Szkolne Komitety Oporu Społecznego.

SKOS-y powstały jako wyraz buntu wobec wprowadzenia w Polsce stanu wojennego. Stopień sformalizowania i aktywności SKOS-ów był mocno zróżnicowany i w efekcie miały one bardziej charakter ruchu społecznego niż zorganizowanej struktury, niemniej organizacja w różnej skali działała na terenie większości

* Dr, Zakład Historii Wychowania, Wydział Studiów Edukacyjnych, Uniwersytet im. Adama Mickiewicza, 60-568 Poznań, ul. A. Szamarzewskiego 89.

1 IPN Po 08/2261/1, Plan realizacji w sprawie nr 9/84, Poznań, 12.04.1984. 
szkół średnich Poznania, tj. w większości liceów ogólnokształcących oraz w niektórych technikach².

Koordynowaniem działalności SKOS-ów zajmowała się Komisja Koordynująca SKOS, która w okresie swej działalności wydawała pismo podziemne pt. "Głos SKOS-ów”, na łamach którego zamieszczano wszelkie informacje mające charakter niepodległościowy. Nie było to jedyne pismo wydawane przez KK SKOS. Oprócz "Głosu SKOS-ów”, KK SKOS-y publikowały również inne pisma podziemne, m.in. „Agora” (nr 1-4 z lat 1986-1987), „Archiwum” (1988-1989), „Echo Dwójki” (1985-1989), „Serwus” (1987)³. Jednak „Głos SKOS-ów”, pismo reprezentujące stanowisko i działania młodzieży opozycyjnej, publikowane było najdłużej, tj. w latach 1982-1989, średnio raz w miesiącu. Stąd na podstawie jego analizy można uzyskać najpełniejszy obraz działalności niepodległościowej uczniów szkół poznańskich w tym okresie.

"Głos SKOS-ów" rozpoczął swą działalność jako kontynuacja publikowanego wcześniej pisma „Wiraż”, ukazującego się w roku 1981. Pierwszy numer „Głosu SKOS-ów", który ukazał się w listopadzie 1982 r. został opatrzony numerem 6.

Pomimo założonych form działania (pismo informacyjno-publicystyczne), za główne zadanie "Głosu SKOS-ów” uważano przede wszystkim agitację działalności opozycyjnej, podziemnej. Periodyk był nastawiony na współpracę z czytelnikami, na umożliwienie nieskrępowanego wypowiadania się młodzieży poznańskich szkół ponadpodstawowych. Redakcja pisma prezentowała też własne dokonania publicystyczne, artykuły dotyczące polskich tradycji politycznych, prowadziła dość szeroką akcję informacyjną, a także - w wyniku mecenatu nad „Głosem...” Komisji Koordynującej Szkolnych Kół Oporu Społecznego - publikowała jej oficjalne dokumenty. Pismo, z racji dość szerokiego zasięgu (jednorazowo drukowano je w nakładzie od 700 do 1000 egzemplarzy), stało się głównym elementem walki z komunizmem na terenie szkół średnich miasta Poznania4.

Edytorsko „Głos SKOS-ów” był dość typowy dla bibuły. Gazetę pisano na maszynie, a powielanie przygotowanej matrycy odbywało się w nielegalnym wydawnictwie na tzw. powielaczach denaturatowych lub spirytusowych ${ }^{5}$. Ze względów bezpieczeństwa często zmieniano miejsce drukowania pisma - były to różne domy prywatne. Ponieważ ówczesne możliwości druku były dość ograniczone, jakość pierwszych numerów „Głosu SKOS-ów” była niezbyt dobra, co obecnie utrudnia odczytywanie tych numerów, które się zachowały ${ }^{6}$. Po kilku latach dzia-

${ }^{2}$ P. Zwiernik, Szkolne Koła Oporu Społecznego, [w:] Encyklopedia Solidarności, http:// www.encyklopedia-solidarnosci.pl/wiki/index.php?title=T01888_Szkolne_Ko\%C5\%82a_Oporu_ Spo\%C5\%82ecznego_Pozna\%C5.

${ }^{3}$ Tamże.

${ }^{4}$ IPN Po 08/2261/5, s. 316.

${ }_{5}^{5}$ Patrz: J. G u l c z y ń s k a, Niezależne pisma młodzieży licealnej (1980-1989) - próba charakterystyki, [w:] Czasopiśmiennictwo drugiej połowy XX wieku jako źródło do historii edukacji, red. I. Michalska, G. Michalski, Łódź 2010, s. 168.

${ }^{6}$ Część numerów „Głosu SKOS-ów” znajduje się w Oddziale Poznańskim IPN. Autorka uzyskała informację o obszernym (być może pełnym) zbiorze numerów pisma, znajdującym się w prywatnym posiadaniu jednego $z$ byłych członków komitetu redakcyjnego, niemniej jednak osoba ta nie wyraziła zgody na udostępnienie zbioru. 
łalności pisma jakość druku uległa znacznej poprawie, również porządek poszczególnych numerów stał się bardziej przejrzysty, co zresztą sygnalizowała sama redakcja w numerze 44. z marca 1986 r. Początkowe numery „Głosu SKOS-ów” liczyły od 2 do 5 stron zapisanych drobnym drukiem. Na stronie tytułowej, u góry znajdowało się logo "Głosu SKOS-ów” i symbol Polski niepodległej, obok numer pisma, miejsce, miesiąc i rok wydania. W kolejnych numerach liczba stron zwiększała się. Wówczas zaczęto coraz częściej przedrukowywać artykuły z innych pism niepodległościowych, mających szerszy zasięg. Najpierw pismo służyło do przekazywania na bieżąco informacji o tym, co się działo w Poznaniu w zakresie poczynań opozycyjnych, z czasem zdobyło znaczenie motywacyjne, edukacyjne, inspirowało do działania.

Od września 1985 do marca 1986 r. pismo nie wychodziło, zostało zawieszone, gdyż bardzo intensywnie interesowały się nim Służby Bezpieczeństwa, które 30 września 1985 r. w godzinach wieczornych rozpoczęły akcję likwidacji nielegalnej organizacji młodzieżowej SKOS. Konsekwencją tego działania były liczne aresztowania najbardziej aktywnych jej członków i przerwanie działalności pisma, które wróciło na „rynek wydawniczy” na początku 1987 r.

Trudno jest dokonać precyzyjnego podziału problematyki tekstów publikowanych na łamach "Głosu SKOS-ów”, gdyż podczas lektury ma się wrażenie raczej spontaniczności zamieszczania materiałów, a nie doboru według określonego klucza czy porządku. Niemniej można dokonać podziału dominujących w piśmie grup tematycznych.

Jedną z nich była szeroko rozumiana polityka, w ramach której prezentowano sytuację bieżącą w kraju, informacje z kraju i ze świata, pozyskiwane najczęściej z zakazanych źródeł, jak Radio Wolna Europa.

Inną grupę publikowanych treści stanowiły odezwy, apele, instrukcje dorosłych opozycjonistów skierowane do młodzieży, w których wspierano młodzieżowe organizacje opozycyjne, instruowano je. Na łamach „Głosu...” opisywano represje wobec osób działających opozycyjnie i czyniono to nie tyle ku przestrodze, ile po to, aby młodzi opozycjoniści, znając szczegółowo zagadnienie, potrafili przygotować się do ewentualnie mogących ich spotkać represji i odpowiednio reagować.

Jednym z głównych obszarów tematycznych prezentowanych w "Głosie...” były różne formy działań niepodległościowych, prowadzone przez Szkolne Koła Oporu Społecznego. W piśmie opisywano zaangażowanie opozycyjne młodzieży, zachęcając jednocześnie do włączenia się w działania niepodległościowe, edukowano czytelników, prowadzono rozważania merytoryczne na wybrane tematy, zamieszczając treści zakazane w szkolnych programach, opisując m.in. w rocznice wybranych wydarzeń prawdziwe ich podłoże. Dość szeroko publikowanym zagadnieniem były losy szkolnictwa w Polsce.

Ponadto w "Głosie SKOS-ów” przedrukowywano ważne teksty z pism niepodległościowych, mających szerszy zasięg, np. „Obserwator Wielkopolski”, „Niepodległość" (pismo ukazujące się w Warszawie i Katowicach) i inne.

Obok wymienionych grup problemowych, pojawiających się w "Głosie SKOS-ów", analiza pisma daje dość wyczerpujący przegląd wydarzeń - głównie działań 
niepodległościowych, jakie miały miejsce w Poznaniu w latach $\mathbf{8 0}$. oraz intensywności zaangażowania się w nie mieszkańców miasta.

W celu wskazania potencjału materiałów publikowanych na łamach „Głosu SKOS-ów" opisano przykłady kilku zagadnień, które ukazują wartość pisma jako źródła do szczegółowych badań działalności opozycyjnej młodzieży poznańskiej w latach 80. Oto kilka z nich.

"Głos SKOS-ów” był kontaktem środowiska solidarnościowego z młodszymi kolegami-opozycjonistami. Na łamach "Głosu SKOS-ów” „Solidarność” publikowała relacje i dokumenty wypracowane podczas jej spotkań. Były to m.in. oświadczenia, instrukcje, apele, informacje. Instruowano o tym, jak należy się zachować w określonych sytuacjach, co robić, czego unikać. Nawoływano do uczestniczenia w wydarzeniach, jak msze św. błagalne lub dziękczynne w określonych intencjach, manifestacje, bojkoty. Już w pierwszym numerze pisma (nr 6) z listopada 1982 „Solidarność Wielkopolska” zamieściła odezwę do młodzieży o następującej treści:

Studenci, Uczniowie, nie jesteście jeszcze członkami Solidarności, ale czekamy na Was. Jesteśmy Waszymi sprzymierzeńcami w walce o lepszą przyszłość. Wiemy, jak wielu z Was cierpi z rąk władzy za chęć zmiany brutalnej, wojennej rzeczywistości na wolną Polskę. Wiemy, że to Was będą brali do bratobójczego wojska morderców w generalskich mundurach. Cieszymy się, że jesteście z nami, bo nie starzy generałowie zmieniają ten świat, lecz młodzi ludzie świadomi swych potrzeb i przekonani o swej sile. Macie dziś dobre warunki do nauki na ulicach, macie dostęp do ludzi bitych. Zdobywajcie wiedzę, organizujcie się w grupy, twórzcie sieci konspiracyjne - przyszłość należy do ludzi zorganizowanych. W wojsku uczcie się bronić ludzi przed wyzyskiwaczami, katami ludzi pracy. Wykorzystujcie Waszą wiedzę teraz w konspiracji, a potem w pracy dla dobra społeczeństwa. Cieszymy się, że jesteście z nami, dziękujemy Wam za pomoc. 6.10.1982 r., za TZR Wielkopolska NSZZ „Solidarność" - Janusz Pałubicki.

Podkreślając ogromne znaczenie zaangażowania opozycyjnego młodzieży i wierząc w nie, zwrócono się następnie z apelem:

Apelujemy do uczniów wszystkich szkół średnich o podjęcie akcji protestacyjnej 10 listopada 1982 r. w odpowiedzi na apel kierownictwa Podziemnej Solidarności dotyczących akcji protestacyjnych w tym dniu. Niech wyrazem naszego sprzeciwu wobec pałkarsko-wojskowej junty będą milczące duże przerwy zakończone odśpiewaniem Hymnu Narodowego, Boże coś Polskę, Roty. Przeprowadzenie innych akcji, jak i ich formę pozostawiamy inwencji poszczególnych SKOS-ów, jak i innych podziemnych organizacji działających w szkołach ${ }^{8}$.

Takie słowa publikowane na łamach „Głosu...” motywowały młodzież do działań niepodległościowych.

Ważnym tragicznym wydarzeniem przedstawionym na łamach „Głosu SKOS-ów” był dramat Grzegorza Przemyka. 17 maja 1983 r. przedstawiciele NSZZ „Solidarność" Regionu Mazowsze, ze Zbigniewem Bujakiem na czele, przedstawili

${ }^{7}$ Archiwum IPN, Oddział w Poznaniu, IPN Po 08/2261/2, Apel podpisał zarząd „Wielkopolska NSZZ Solidarność” - Janusz Pałubicki, „Głos SKOS-ów”, Pismo Komisji Koordynującej Szkolnych Kół Oporu Społecznego [dalej: G] 1982 (II), nr 6 (listopad), s. 2.

8 Tamże, s. 1. 
w numerze 137. Informacji Solidarności Regionu Mazowsze szeroki opis ukazujący okoliczności brutalnego pobicia w maju przez MO maturzysty Grzegorza Przemyka, który w wyniku obrażeń zmarł. Redakcja "Głosu SKOS-ów”9 przedstawiła ten tekst na łamach swojego pisma, chcąc przekazać czytelnikom, w jak przerażający sposób władza potraktowała młodego człowieka, ich rówieśnika. Opis całego zdarzenia wywołuje ogromne napięcie, mobilizując do działań opozycyjnych.

W marcu 1984 r. Solidarność na łamach „Głosu SKOS-ów” wzywała „komisje zakładowe, redakcje pism podziemnych, organizacje i grupy oporu do podjęcia akcji uświadamiających kłamliwy charakter wyborów [jakie wówczas miały się odbyć] i konieczność [ich] bojkotu"10.

$\mathrm{Na} ł a m a c h$ "Głosu SKOS-ów” zamieszczano też informacje i nawoływano o pomoc dla represjonowanych. Pierwszy taki apel ukazał się w numerze 6. z listopada 1982 r. i został zamieszczony przez Redakcję „Obserwatora Wielkopolskiego", która stworzyła na ten cel Fundusz Pomocy dla Represjonowanych. Redakcja "Obserwatora” apelowała wówczas o zbieranie składek od czytelników, którzy mieli przekazywać je poprzez kolporterów wraz z pseudonimem, pod jakim miało się ukazać potwierdzenie odbioru wpłaty.

Dominującym obszarem rozważań w piśmie „Głos SKOS-ów” były zamieszczane tam obszerne opisy prowadzonych przez młodzież, głównie pod auspicjami Szkolnych Kół Oporu Społecznego, form działalności opozycyjnej.

Jedną z nich były tzw. „Ciche przerwy w szkołach”. Od samego początku SKOS-y organizowały w szkołach średnich Poznania, zwłaszcza w liceach ogólnokształcących, tzw. „ciche przerwy” jako wyraz buntu przeciwko ówczesnej polityce, jako reakcja na mające wówczas miejsce zajścia. Odbywały się one zazwyczaj podczas przerwy między trzecią i czwartą lekcją. Przerwy takie miały miejsce zwykle w rocznice ważnych wydarzeń, jak wprowadzenie stanu wojennego czy pacyfikacja w Kopalni „Wujek”. W notatkach Wydziału III-1 KWMO Poznań wymieniano najczęściej licea nr II i VIII w Poznaniu jako szkoły, w których organizowano takie „ciche przerwy”11. W "Głosie SKOS-ów” precyzyjnie te wydarzenia opisywano, naświetlając jednocześnie czytelnikowi sens takiej formy buntu, co niewątpliwie uświadamiało i mobilizowało do działań w tym zakresie - w „cichych przerwach" uczestniczyła zwykle większość uczniów szkoły. Zorganizowaną m.in. w przeddzień rocznicy odzyskania przez Polskę niepodległości "cichą przerwę" w „Głosie SKOS-ów” opisano następująco:

"Ciche przerwy" miały miejsce w II, IV, VI i XI LO oraz w Zespole Szkół Elektrycznych w Poznaniu. Młodzież gromadziła się w wyznaczonych miejscach, śpiewała Hymn Narodowy, Boże coś Polskę i Rotę. W „Cichych przerwach” brało udział przeciętnie 90\% szkoły (w Zespole Szkół Elektrycznych $50 \%$ ). W XI LO wyrzuceni przez dyrektora ze szkoły uczniowie, zgromadzili się na boisku wokół znicza i kartki z napisem „Ofiarom wojny - XI LO”. Dyrektor groził rozwiązaniem szkoły. W II LO „Cicha

${ }^{9}$ Archiwum IPN, Oddział w Poznaniu, IPN Po 08/2261/2, G 1983, nr 13 (czerwiec), s. 2-3.

10 Archiwum IPN, Oddział w Poznaniu, IPN Po 00/206/105/cz. 3, Apel podpisał zarząd „Wielkopolska NSZZ Solidarność" - Janusz Pałubicki, G 1984, nr 23 (marzec), s. 1.

11 IPN Po 08/2261/1. Plan czynności operacyjnych do sprawy operacyjnego rozpracowania krypt „Skos”, nr rej. 33 147, Poznań, 10.02.1983. 
przerwa" odbyła się po raz drugi w asyście dwóch funkcjonariuszy SB. VIII LO - przed Kościołem MB Bolesnej znajdującym się naprzeciwko szkoły ułożono krzyż z kwiatów. W czasie dużej przerwy zaczęli się tam gromadzić uczniowie. Odśpiewano Boże coś Polskę i odmówiono litanię „Solidarności”. Zgromadzenie obserwował z okna pokoju dyrektora specjalista od szkół poznańskich por. SB. Krzyż przed Kościołem rośnie. Indagowany przez SB proboszcz odmówił zlikwidowania krzyża. Wobec tego SB podjęło w nocy próbę zniszczenia krzyża - rozkopano go butami. Akcja „cichych przerw” poprzedzona została akcją malowania haseł na murach szkół. Z okna II LO od ulicy Matejki wywieszona została 10.11. flaga „S”, która wisiała 45 min., zanim nie zdjęła jej milicja. [... $]^{12}$.

Poza „cichymi przerwami”, w ramach działań opozycyjnych młodzież rozprowadzała w szkołach różnej treści ulotki o wydźwięku niepodległościowym. W „Głosie...” zamieszczano bardzo szczegółowe informacje na ten temat. Oto relacje z akcji, jaka odbyła się w I LO w Poznaniu w kwietniu 1984 r.:

W poniedziałek 02.04.84 r. na przerwach pojawiły się ulotki z fragmentami kazania Prymasa oraz informacją o sytuacji w garwolińskich szkołach. Kolejne, które można było znaleźć w szkole w czwartek, informowały o "cichej przerwie” mającej odbyć się następnego dnia po 3 lekcji. Wszystkie zostały wyzbierane przez uczniów i grono profesorskie, z tym, że część nauczycieli po uczniowsku, podnosiła po dwie, trzy i ze strachu oddalała się od tych miejsc, a inni, na czele z panem profesorem R. [nazwisko], zapełniali nimi kosze. Następnego dnia rano w budynku szkoły stan oblężenia - w holu stoi przyglądający się uczniom przez wszystkie lekcje i przerwy woźny, po schodach i piętrach krążą nauczyciele. Mimo to przed wejściem do szkoły leżą te same, co dnia wczorajszego ulotki. Na trzeciej lekcji poprzedzającej przerwę w klasach pojawiają się wychowawcy. Informują o tym, że wczoraj i dziś była w szkole bibuła, a do dzienniczków polecają wpisać informację o grożących za jej rozpowszechnianie i protesty przeciwko zdejmowaniu krzyży sankcjach. Na samej przerwie duże zaskoczenie dyrekcja zmusiła klasę dyżurną do wystawienia kolumn nagłaśniających i przeprowadzenia wyborów miss szkoły. Wychodzących z sal lekcyjnych powitały dźwięki muzyki rockowej. Po pierwszym zaskoczeniu, większość uczniów z holu przechodzi do stołówki - tam zapanowuje cisza, którą przerywa dopiero interwencja dyrektora B. [nazwisko] starającego się zmusić wszystkich do wyjścia stamtąd. Nie udaje mu się to i w końcu odchodzi. Przed kolumnami około 50 osób obserwuje wybory, a nawet próbuje klaskać (kandydatki były dwie). Po dzwonku wszyscy rozchodzą się do klas ${ }^{13}$.

Relacja ta w sposób bardzo szczegółowy i wszechstronny ukazuje wielowątkowość wydarzenia, reakcje rożnych osób na nie, a tym samym odbiór danej sytuacji przez środowisko szkolne, z jednej strony uczniów, z drugiej nauczycieli. I jakże różne postawy poszczególnych osób wobec zdarzenia.

Szkolne Koła Oporu Społecznego z całym oddaniem walczyły o krzyże w szkołach poznańskich. Informacje na ten temat również skrupulatnie zamieszczano na łamach „Głosu SKOS-ów”. Głośna była wówczas sprawa walki o krzyże w Zespole Szkół Rolniczych im. St. Staszica w Miętnem k. Garwolina. Czytelnicy „Głosu..." poznali ją ze stron pisma. Walka o to, aby w szkołach na ścianach wisiały krzyże, toczyła się z różnym nasileniem w ciągu całego okresu Polski Ludowej. Z początkiem lat 80., w sytuacji kilkumiesięcznego „oddechu solidarnościowego" krzyże w szkołach się pojawiały. Jednak w kolejnych latach władze czyniły wszystko, aby z nich znikały. Młodzież działająca w opozycji walczyła o nie na różne sposoby. W jednej z ulotek czytamy:

12 Archiwum IPN, Oddział w Poznaniu, IPN Po 08/2261/2, G 1982 (II), nr 7 (listopad), s. 2.

${ }^{13}$ Archiwum IPN, Oddział w Poznaniu, IPN Po 00/206/105/cz.3, Cicha przerwa w I LO, „Głos SKOS-ów", Pismo Komisji Koordynującej Szkolnych Kół Oporu Społecznego, nr 24, Poznań, kwiecień 1984, s. 3. 
Pamiętajmy! W historii Polski niejednokrotnie symbol krzyża pozwolił przetrwać narodowi ciężkie chwile. I w obecnej sytuacji stanowi on dla nas źródło wiary, nadziei i jedności. Dlatego nie pozwólmy na zdjęcie krzyży ze ścian naszych szkół. W przypadku takich sytuacji organizujmy na terenie budynków szkolnych strajk okupacyjny. Liczymy na solidarność wśród młodzieży Poznania. KK SKOS ${ }^{14}$.

Ulotka ta pojawiła się 16 marca 1984 r. w liceach poznańskich nr I, II, VI, VIII, IX. Wówczas krzyże do szkół wróciły. Z początkiem roku szkolnego 1986/1987 sytuacja się powtórzyła. W numerze 48. „Głosu SKOS-ów” z 10 września 1986 r. zamieszczono informację o zniknięciu krzyży z poznańskich liceów. W poniedziałek 1 września 1986 r., kiedy uczniowie liceów poznańskich nr III, IV, VII, IX i X wrócili po wakacjach do szkół, zauważyli, że z sal szkolnych zniknęły krzyże. Zwrócili się do dyrekcji poszczególnych szkół z zapytaniem o los krzyży, a następnie zażądali natychmiastowego przywrócenia krzyży do szkół. Apelowano do organizacji opozycyjnych, a także do legalnych środków społecznych o poparcie poznańskich licealistów w walce o krzyże w szkołach. Jak napisano:

Apelujemy o przeprowadzenie akcji informacyjnych, o redagowanie i wysyłanie petycji i listów protestacyjnych, o domaganie się wyjaśnień. Ze szczególną ufnością zwracamy się do rodziców uczniów z III, IV, VII, IX, X LO. Tak wiele zależy dziś również od naszej postawy. Dorośli! Pomóżcie nam! KK SKOS.

Nie we wszystkich liceach zdjęto krzyże. Nie zrobiono tego w LO nr I, II i VIII. Zdjęte krzyże w niektórych placówkach uczniowie próbowali samodzielnie powiesić. Niestety, nie spotkało się to z przychylnością władz szkolnych - krzyże zdejmowano ponownie. W intencji powrotu krzyży do szkół odbywały się msze św. Uczniowie w ramach protestu organizowali „ciche przerwy” 15 .

W walce o przywrócenie krzyży w szkołach powołano Komitet Obrony Krzyża. Przygotowywano i kolportowano apele do społeczeństwa z prośbą o pomoc w walce o krzyż. Wszelkie informacje na ten temat zamieszczano na łamach „Głosu...”

Formą pracy SKOS-ów był tzw. Młodzieżowy Sąd Podziemny, który sądził i wydawał wyroki m.in. na dyrektorów tych szkół średnich, którzy współpracowali ze Służbami Bezpieczeństwa. Młodzieżowy Sąd Podziemny wysyłał do dyrektorów tych listy zawierające wyroki. Służby Bezpieczeństwa prowadziły śledztwa w takich sprawach, próbując ustalić personalia członków SKOS-ów zaangażowanych w Młodzieżowym Sądzie Podziemnym ${ }^{16}$. Na łamach "Głosu SKOS-ów” publikowano wyroki i ich uzasadnienia, a także informacje o ich wykonaniu, m.in. 26 stycznia 1983 r. po rozpoznaniu na posiedzeniu niejawnym przy udziale przewodniczącego Międzyszkolnej Komisji Koordynacyjnej Podziemnej Solidarności Młodzieży zapadł wyrok dotyczący kilku dyrektorów szkół średnich w Poznaniu, poprzedzony oskarżeniem ich o:

14 IPN Po 00/206/105/cz. 3, ulotka, marzec 1984, s. 164.

15 Archiwum IPN, Oddział w Poznaniu, IPN Po 08/2261/7, Żądamy natychmiastowego przywrócenia krzyży do szkół, G, 10.09.1986, nr 48, s. 30.

${ }^{16}$ IPN Po 08/2261/1, Groźba pisemna (anonim pogróżkowy) wobec działaczy polityczno-społecznych, Poznań, 3.02.1983. 
1. Zdradę Ojczyzny; 2. Członkostwo i czynne działanie w nielegalnej, przestępczej, faszystowskiej organizacji pod nazwą: Polska Zjednoczona Partia Robotnicza; 3. Bezprawne objęcie stanowisk dyrektorów kilku szkół i bezprawne pozostawanie na nich; 4. Bezprawne wyrzucenie z pracy kilku nauczycieli w roku szkolnym 1981/82; 5. Represjonowanie nauczycieli - członków NSZZ „Solidarność”; 6. Represjonowanie młodzieżowych działaczy demokratycznych i samorządowych; 7. Represjonowanie uczniów działających w podziemiu; 8. Uniemożliwienie zorganizowania prawdziwych samorządów szkolnych; 9. Wytworzenie w szkołach atmosfery zastraszania wśród uczniów i nauczycieli; 10. Podejmowanie bezprawnych działań zmierzających do wykrycia i zlikwidowania podziemia młodzieżowego w szkołach; 11. Działanie na szkodę uczniów i nauczycieli przez cały okres pozostawania na stanowiskach dyrektorów szkół; 12. Wzywanie na teren szkół funkcjonariuszy SB, MO i ZOMO; 13. Uniemożliwienie powieszenia oraz zdejmowanie już powieszonych krzyży w szkołach; 14. Szkalowanie przywódców i członków NSZZ „Solidarność”17.

Z publikowanego postanowienia Sądu wynikają cenne informacje na temat postaw i działań części dyrektorów szkół poznańskich. Wyroki publikowano na łamach "Głosu SKOS-ów” jako Komunikat do wszystkich skazanych, w którym w tonie zastraszania nakazywano dyrektorom podporządkować się wytycznym młodzieży. Realizacja wyroków była mało realna, niemniej wyrażała odwagę osób, które je przygotowywały, a także determinację, z jaką oddawały się opozycyjnemu działaniu. Przykładem niech będzie poniższy fragment:

Komunikat do wszystkich skazanych: 1. Nakazuję wszystkim skazanym odczytanie w szkołach treści wyroku wraz z uzasadnieniem na specjalnym apelu lub przez radiowęzeł szkolny, jeśli takowy w szkole jest; 2. Szczególnie przestrzegam skazanych przed przekazaniem wyroku organom MO lub SB. Ostrzegam, że mamy dość środków, aby przeciwdziałać działalności MO lub SB na terenie szkół. Każdy funkcjonariusz MO, ZOMO lub SB, który wkroczy na teren którejkolwiek ze szkół w celu prowadzenia śledztwa w sprawie wyroku, zostanie rozbrojony i aresztowany. W w/wym. przypadku dyrektor tej szkoły zostanie aresztowany i wykonanie wyroku zostanie przyspieszone; 3. W szkołach, w których skazani dotychczas pracowali, Rady Pedagogiczne powinny w jak najkrótszym czasie, w drodze konkursu wybrać nowego dyrektora ${ }^{18}$.

Wszystkie te działania były bardziej „pobożnymi” życzeniami młodych opozycjonistów, aniżeli możliwymi do zrealizowania zagadnieniami. Niemniej z pewnością mobilizowały młodzież i wywoływały nadzieję na zmiany.

Działania niepodległościowe młodzieży poznańskiej były ścigane. Młodych ludzi często poddawano różnego rodzaju represjom, jak inwigilacja, areszty, przesłuchania, wyroki, więzienia. Dla młodych ludzi były to przeżycia straszne, okrutne. Niestety, niejedną osobę złamały. Aby temu zapobiec, aby wzmocnić młode charaktery, na łamach "Głosu SKOS-ów” zamieszczano tzw. niezbędne informacje dotyczące aresztowań przez MO, SB. W numerze 30. „Głosu...”, jak napisano:

Na prośbę wielu czytelników, a także idąc za radą kolegów, którzy mają za sobą pobyt w areszcie lub więzieniu, postanawiamy opublikować cenne wskazówki dla aresztowanych. Doświadczenie uczy, że główna część dowodów uzyskanych podczas śledztwa oparta jest na zeznaniach podejrzanych. W związku z tym chcemy przekonać naszych czytelników do kilku generalnych zasad: 1 . W razie rewizji, aresztowania lub zwykłego zatrzymania - nie dać się zastraszyć; 2. Nic nie mówić.

\footnotetext{
17 Archiwum IPN, Oddział w Poznaniu, IPN Po 08/2261/2, G 1982 (II), nr 7 (listopad), s. 2.

18 Tamże, s. 3.
} 
W ogóle odmawiać zeznań lub nie odpowiadać na poszczególne pytania. Nawet szczegóły pozornie nieistotne są pomocą dla Esbecji i Milicji. Porady, które będziemy drukować, napisano przed kilku laty i zamieszczono w książeczce zatytułowanej „Mały konspirator” w rozdziale „Gra w śledztwo” 19.

Następnie w kolejnych numerach pisma zamieszczano całe fragmenty opisujące, jak należy się zachować $w$ tak niebezpiecznej sytuacji, co niewątpliwie pomagało wielu młodym ludziom przetrwać w sytuacjach zagrożenia.

W „Głosie SKOS-ów” drukowano relacje z odbywających się w Poznaniu manifestacji, dzięki czemu czytelnicy mogli uzyskać informacje o nich bez cenzury. Bardzo precyzyjny opis wydarzeń na pewno przemawiał do młodzieży, mobilizując ją do podjęcia działań niepodległościowych. Oto wymowny fragment takiego opisu:

O godz. 16.00 rozpoczęła się Msza św. w Kościele OO Dominikanów na ulicy Stalingradzkiej. Jeszcze przed końcem mszy św. w okolicy kościoła zaczęły gromadzić się grupy młodzieży. Wychodzący z kościoła ludzie nie rozchodzą się do domów. W pewnym momencie rozrzucono ulotki z podobizną Lecha Wałęsy. Ludzie zaczynają skandować „Lechu, Lechu” i „Solidarność”. Następnie tłum (około 1,5 tys. osób) rusza w kierunku Pomnika Poznańskiego Czerwca 1956 r. ${ }^{20}$

Redakcja „Głosu...” bardzo aktywnie brała udział w przygotowywaniu 30. rocznicy poznańskiego Czerwca 1956. W reaktywowanym od marca $1986 \mathrm{r}$. „Głosie SKOS-ów” zamieszczono program obchodów niezależnych owej rocznicy. Program informował o odbywających się mszach św. w intencji poległych wówczas osób, informował, gdzie, kiedy i o której zostaną odprawione takie msze, kto będzie w nich uczestniczył, na jaki temat będzie wygłoszona homilia. Mszom św. towarzyszyły projekcje filmów, odczyty, programy inscenizacyjne, prelekcji na temat Czerwca 1956 r. Redakcja mobilizowała czytelników słowami:

Wzywamy wszystkich, którym drogie są idee, których wyrazem była walka poznańskich robotników sprzed trzydziestu lat, aby włączyli się do akcji planowanych na czerwiec. Przede wszystkim tych niezależnych, organizowanych przez wolne ośrodki społeczne i polityczne, głównie NSZZ "Solidarność". Apelujemy o zrozumienie dla rangi tej rocznicy, dla znaczenia, jaką ma nasza postawa dziś. Dbajmy, aby hierarchia nie mogła nam zarzucić braku szacunku i poczucia odpowiedzialności wobec wywalczonych wartości. Jesteśmy zobowiązani do zrozumienia historycznej wagi wydarzeń w 1956 r. Nie wolno nam zaprzepaścić politycznego kapitału wywalczonego przez nasz naród 30 lat temu. Niech nasz udział w niezależnych obchodach rocznicy Czerwca 1956 r. będzie sprawdzianem sumienia patriotycznego każdego z nas. Poznań, 21 maja 1986 r., Komisja Koordynująca Szkolnych Kół Oporu Społecznego ${ }^{21}$.

Obok treści o zakresie regionalnym, na łamach „Głosu SKOS-ów” publikowano wiele tekstów o szerszym zasięgu, będących przedrukami z innych nielegalnych wydawnictw, jak „Obserwator Wielkopolski”, „Niepodległość”, „Solidarność Walcząca” czy „Solidarność Zwycięży”. Były wśród nich rozważania na temat wizyty Papieża Jana Pawła II w Polsce w czerwcu 1983 r. Zamieszczano fragmen-

${ }^{19}$ Archiwum IPN, Oddział w Poznaniu, IPN Po 08/2261/5, G 1984, nr 30 (wrzesień), s. 2.

${ }^{20}$ Archiwum IPN, Oddział w Poznaniu, IPN Po 08/2261/2, G 1982 (II), nr 7 (listopad), s. 1.

${ }^{21}$ Archiwum IPN, Oddział w Poznaniu, IPN Po 08/2261/7, 30-ta rocznica obchodów Poznańskiego Czerwca 1956 r., Program uroczystości (obchody niezależne), G 1986, nr 44 (marzec), s. 30. 
ty homilii, które Papież wygłaszał w poszczególnych odwiedzanych miastach. W „Głosie..." znaleźć można głównie fragmenty adresowane do młodych, zdania bardzo wymowne, głębokie, które stały się z czasem fundamentem kształtowania Pokolenia JPII. Znajdujemy też teksty wypowiedzi Lecha Wałęsy oraz sprawozdania z działań NSZZ „Solidarności”.

Od 1987 r. zauważa się znaczne zmniejszenie akcji inicjowanych przez SKOS-y. Jak zanotowano w dokumentacji SB, do końca października 1986 r. było 47 różnego rodzaju akcji protestacyjnych, natomiast w roku 1987 było ich już tylko 11. Zauważyć można akcyjność prowadzonych działań, które wynikały z bieżącej sytuacji społecznej i różnych wydarzeń w kraju. Od maja 1987 r. organizacja SKOS poprzestawała często na wydawaniu ulotek okolicznościowych ${ }^{22}$.

W czasie tym coraz częściej na łamach "Głosu SKOS-ów” zaczęły pojawiać się treści zapowiadające rychłe zmiany. Pierwszymi tego symptomami były publikowane dyskusje na temat szans Polski na dialog, w których pisano: „Zaczynamy mieć nadzieję, że Polska może być krajem nie tylko dla władzy, ale także dla społeczeństwa świadomego swoich praw i potrzeb, jak i zagrożeń"23.

Jednym z istotnych tematów, jakie wówczas poruszano na łamach „Głosu...”, było szkolnictwo. Analizowana tam tematyka stała się istotnym wprowadzeniem w zagadnienia edukacji polskiej i konieczności jej zmiany w czasie obrad Okrągłego Stołu oraz później, w pracach nad zmianami w programach szkolnych. Jednym $z$ artykułów na ten temat był tekst, w którym dokonano trafnych spostrzeżeń na temat ułomności ówczesnego polskiego systemu oświatowego, pisząc: „polski system edukacyjny należy do najbardziej niewydolnych i zacofanych w Europie". Dalej nawiązano do wprowadzanej wówczas do szkolnictwa średniego reformy programowej (zrezygnowano wówczas z reformy strukturalnej, ale kontynuowano reformę programową). Autorka tekstu zauważa, iż nowy program jeszcze bardziej pogłębi krytyczny stan szkoły polskiej ${ }^{24}$.

Troszcząc się o szkołę polską, od roku 1988 na łamach „Głosu SKOS-ów” zamieszczano ramowy program działalności SKOS-ów w szkołach, sprowadzający się do następujących problemów: walka o respektowanie limitu 31 godzin lekcyjnych w tygodniu; usunięcie lub ograniczenie nadobowiązkowych przedmiotów, np. religioznawstwa, problemów współczesnej cywilizacji, podstaw ekonomii, przysposobienia obronnego; dążenie do usunięcia z egzaminów maturalnych przedmiotu podstawy nauki o społeczeństwie (PNOS); dążenie do powrotu do szkół zdjętych krzyży ${ }^{25}$.

Zabiegając o dobrą przyszłość szkoły, w marcu 1989 z inicjatywy SKOS-ów do Kuratorium Oświaty i Wychowania w Poznaniu przybyła grupa młodzieży delegacja uczniów reprezentujących szkoły ogólnokształcące w Poznaniu, która

22 IPN Po 08/2261/1, Informacja dot. nielegalnej organizacji „SKOS” oraz prowadzonych przeciwdziałań, Poznań, październik 1987.

${ }^{23}$ Archiwum IPN, Oddział w Poznaniu, IPN Po 08/2261/7, Czy istnieje szansa na dialog, G 1986, nr 50, s. 125.

${ }^{24}$ Archiwum IPN, Oddział w Poznaniu, IPN Po 08/2261/7, A. P o t o ck a, Fabryka przeciętnych, G 1986, nr 44 (marzec), s. 4.

${ }^{25}$ IPN Po 08/2261/1, Meldunek uzupełniający nr 170/88 do sprawy operacyjnego rozpracowania krypt. „SKOS” nr rej. 33147, nr identyfikatora 6693/85, Poznań, 20.09.1988. 
złożyła petycję dotyczącą reformy nauczania, kierowaną do Ministerstwa Edukacji Narodowej, w sprawie m.in. zniesienia przedmiotów nauczania takich, jak filozofia, religioznawstwo, ekonomia, socjologia, ograniczenie $\mathrm{PO}^{26}$.

W czerwcu 1989 r., kiedy w Polsce rozpoczął się proces zmian, SKOS-owcy zaczęli angażować się już oficjalnie w realizację celów, o które dotąd walczyli w podziemiu. Jednym z obszarów były wysuwane $w$ ramach propozycji zmian w szkolnictwie polskim petycje sprzeciwiające się indoktrynacji podczas lekcji PNOS-u, czy domagające się ograniczenia zajęć z przysposobienia obronnego. Postulaty te znajdowały poparcie licealistów, publikowane też były na łamach "Głosu SKOS-ów". Petycja ta odbiła się szerokim echem w środowisku. W ramach jawnej działalności członkowie SKOS-ów, aby formalnie prezentować swoje stanowisko, aktywnie angażowali się w prace samorządów szkolnych, chociaż nie do końca wówczas uczniowie byli przekonani do takiej formy pracy - większość z nich nie ufała szkole, w której nadal panowały obostrzenia i nieufność. Poza tym SKOS-owcy angażowali się w najróżniejszych obszarach, jak np. manifestacjach ekologicznych, kościelnych imprezach kulturalnych czy innych, jak określano, „zadymach”, w których można było zaistnieć. Sami o sobie pisali: „u nas nie wyznacza się zadań i najogólniej można powiedzieć, że angażujemy się we wszystko to, co rozszerza demokrację"27. Tak też można określić działania SKOS-ów - jako wszelkiego rodzaju przedsięwzięcia, które - zdaniem uczestników - służyły budowie demokracji.

Dnia 10 czerwca 1989 r. podczas spotkania w Gdańsku niezależnych organizacji młodzieżowych powołano ogólnopolską organizację pn. Niezależna Unia Młodzieży Szkolnej. Do organizacji tej SKOS poznański zgłosił swój akces i zawiesił swą działalność we wszystkich szkołach Poznania i poza terenem, a jego członkowie, po wyrażeniu zgody, przeszli do nowo powstałego NUMS-u ${ }^{28}$. Zaprzestano też wydawania „Głosu SKOS-ów”.

\section{Zakończenie}

Intensywność zmian, jakie zachodziły w Polsce podczas całej dekady lat 80 ., wywoływała również znaczne przeobrażenia wśród młodych opozycjonistów, co przełożyło się na treści zamieszczane na łamach „Głosu SKOS-ów”. Tak więc po pierwszych latach ogromnego napięcia politycznego, kluczowych dla Polski wydarzeń, jak stan wojenny, jego zawieszenie i wszelkie tego konsekwencje, w drugiej połowie lat 80 ., pod wpływem zmieniającego się krajobrazu politycznego w Polsce, opozycja zaczęła zmieniać swoją postawę. Zauważa się to również wśród młodzieżowych grup niepodległościowych. Na łamach "Głosu SKOS-ów”

${ }^{26}$ IPN Po 08/2261/1, Meldunek uzupełniający $\mathrm{nr}$ 186/88 do sprawy operacyjnego rozpracowania krypt. „SKOS” nr rej. 33147, nr identyfikatora 6695/85, Poznań 10.03.1989.

27 SKOS-em, ale dokąd?, „Głos Wielkopolski”, 14.06.1989.

${ }^{28}$ IPN Po 08/ 2261/1, Meldunek uzupełniający $\mathrm{nr}$ 147/89 do sprawy operacyjnego rozpracowania krypt. „SKOS” nr rej. 33147, nr identyfikatora 6693/85, Poznań 19.09.1989. 
przełożyło się to na merytoryczne dyskusje na określone tematy, które z czasem stały się wprowadzeniem w zagadnienia, które z końcem lat 80., w kontekście okoliczności związanych ze zmieniającym się w naszym kraju ustrojem, inicjowały często owe zmiany.

Teksty zamieszczane na łamach „Głosu SKOS-ów” ukazują chronologię wydarzeń związanych z działalnością opozycyjną. Analiza zawartości tego pisma daje w zasadzie pełen obraz tej działalności w latach 1982-1989 w Poznaniu realizowanej przez młodzież. Jest bardzo wiele artykułów będących relacjami, sprawozdaniami, opisami tego, co działo się na ulicach czy w szkołach. W tekstach pisanych przez młodych redaktorów dostrzec można pewnego rodzaju naiwność, ślepą wiarę $w$ to, że można wszystko zmienić i należy to czynić zdecydowanie. Brakuje refleksji, ostrożności czy dyplomacji w działaniach. Niemniej trzeba to przypisać „skrzydłom młodości”, która nie widzi niebezpieczeństwa, nie chce go widzieć, sunie śmiało do przodu w nieprzepartej nadziei, że wszystko musi się zakończyć sukcesem. Tak było wówczas w wielu przypadkach i tylko zderzenie z brutalną rzeczywistością (aresztowanie, pokój przesłuchań, cela więzienna) powodowało podejmowanie środków bardziej ostrożnych, rzadko rezygnowano jednak z raz obranej drogi „ku wolności”. 